\title{
LEITURA DE POESIA PARA JOVENS: A LÍRICA DO METRÔ DE SÉRGIO CAPPARELLI'
}

\section{POETRY READING TO YOUNG PEOPLE: THE LYRIC OF SÉRGIO CAPPARELLI'S SUBWAY}

\author{
José Hélder Pinheiro Alves² \\ Lívia Marbelle Oliveira Barboza ${ }^{3}$
}

RESUMO: Este artigo tem como objetivo refletir sobre a poesia juvenil e formas de aproximação com o seu público. Nossa reflexão terá como base o livro de poemas O rapaz do metrô: poemas para jovens em oito chacinas ou capítulos, de Sérgio Capparelli (2014). Primeiramente, dialogamos com as reflexões de Martha (2012) Pinheiro (2018) e Silva (2009) relativas ao gênero e, a seguir, lançamos mão de Cademartori (2012) acerca das narrativas policiais contemporâneas, uma vez que a obra constrói-se também sob esta perspectiva. Posteriormente, baseados na noção de poesia enquanto jogo de Iser (2002), apresentamos uma experiência com um poema da obra. Concluímos que, mais do que temáticas, e eu líricos identificáveis pelo leitor, para que a leitura seja significativa, é preciso pensar em como as temáticas são abordadas (dimensão estética) e como mediadores lançam mão de estratégias que favoreçam o diálogo textos versus leitor.

PALAVRAS-CHAVE: Poesia juvenil. Sérgio Capparelli. Ensino de poesia.

ABSTRACT: This article has as an objective to reflect upon Juvenile poetry and the forms of approach with its audience. Our reflection will have as a base the book of poems $O$ rapaz do metro: poemas para jovens em oito chacinas ou capítulos, by Sérgio Capparelli (2014). Firstly, we dialogue with Martha (2012), Pinheiro (2018), and Silva (2019) reflections related to the gender and, then, we resort to Cademartori (2012) about the contemporary police narratives, since the piece is also built under this perspective. Posteriorly, based on the notion by Iser (2002) of poetry as a game, we present an experiment with a poem from the piece. We concluded that more than a theme and a lyrical subject identifiable by the reader, it is necessary for a meaningful reading to think about how the thematics are approached (aesthetic dimension) and how mediators use strategies that favor the dialogue between text versus reader.

KEYWORDS: Juvenile Poetry. Sérgio Capparelli. Poetry teaching.

\footnotetext{
${ }^{1}$ Artigo recebido em 15/04/2020 e aceito para publicação em 20/06/2020.

${ }^{2}$ Professor doutor, pertencente ao quadro docente permanente do Programa de Pós-Graduação em Linguagem e Ensino (PPGLE) da Universidade Federal de Campina Grande (UFCG) na área de Estudos Literários. E-mail: helder.pinalves@gmail.com. ORCID: 0000-0003-4304-7178.

${ }^{3}$ Mestranda do Programa de Pós-Graduação em Linguagem e Ensino da Universidade Federal de Campina Grande (UFCG), desenvolvendo pesquisa em Estudos Literários na linha de pesquisa Ensino de Literatura e formação de leitores. E-mail: liviamarbelle@gmail.com. ORCID: 0000-0002-0895-0831.
}

Interdisciplinar, Sầo Cristóvăo, UFS, v. 33, jan-jun, p. 30-47, 2020 D0I: https://doi.org/10.47250/intrell.v33i1.14175 


\section{Introduçầo}

Ao olharmos para o que se denomina poesia infanto-juvenil, percebe-se, ainda hoje, uma produção mais direcionada para o público infantil. Da mesma forma, como consequência da escassez de uma poesia juvenil, os estudos acerca dessa literatura também são, em sua maioria, sobre obras voltadas para crianças. Em um dos poucos estudos sobre o trabalho com o poema com jovens leitores, Pinheiro $(2000 ; 2018)$ aponta como um caminho para suprir a pouca produção voltada para esta faixa etária, a elaboração de antologias a partir da obra de poetas consagrados.

Este artigo tem por objetivo refletir sobre a produção da poesia juvenil e as suas formas de aproximação com o seu público leitor, lançando mão, para isso, de uma leitura de $O$ rapaz do metrô: poemas para jovens em oito chacinas ou capítulos, de Sérgio Capparelli (2014). O livro tem como protagonista um jovem com 16 anos, da periferia de São Paulo, que vivencia uma situação de grande violência em seu bairro. A obra tem um fio narrativo que conduz os poemas pelas linhas do metrô da cidade, após, acidentalmente, o eu lírico filmar um assassinato. A partir daí, o jovem passa a temer por sua vida e o metrô será o espaço escolhido para refletir sobre o que fazer.

Posto isto, propomos um olhar sobre a produção de poemas para jovens na nossa literatura. Primeiramente, dialogamos com as reflexões de Martha (2012), Pinheiro (2000; 2018) e de Silva (2009) acerca do gênero poesia; em seguida, recorremos, principalmente, à Cademartori (2012) sobre as narrativas policiais, considerando que a obra está construída também sob esta perspectiva. Por fim, a partir da noção do texto enquanto jogo (ISER, 2002), apresentamos uma experiência com alunos do ensino médio.

\section{Poesia para jovens leitores}

Os poemas voltados para os mais jovens podem ser caracterizados por uma preocupação com o receptor, considerando, sobretudo, o seu desenvolvimento cognitivo. No entanto, crianças e adolescentes percebem o mundo e se colocam nele de diferentes formas, o que também acontece com os seus objetos de interesse. Por essa perspectiva, uma poesia pensada para a infância pode não 
ser atraente para o leitor adolescente, assim como um poema sobre as questões da juventude pode ser desinteressante para a criança.

Diante da grande produção infantil brasileira, o que podemos observar em estudos, como a tese de doutorado de Silva (2009) é uma escassez de poemas para adolescentes, sobretudo de obras com valor estético. Nessa tese, foram analisadas diversas obras de poemas para jovens e constatou-se que a linguagem de muitos desses textos não apresenta um trabalho artístico considerável, além da presença de uma tendência moralista e prosaica, indo de encontro com a própria natureza do gênero:

[...] a linguagem dos textos não revela um trabalho artístico considerável, caindo muitas vezes no lugar comum. São raros os livros de poesia com qualidade estética voltada para os adolescentes, diferentemente do que acontece com a poesia destinada ao público infantil. (SILVA, 2009, p. 106 - 107).

A opacidade que há nas palavras da linguagem poética não deveria ser negada nos poemas para o público jovem, mas ser compreendida como um convite para desbravar os possíveis sentidos do texto. Os poemas para essa faixa etária, baseando-se nos pressupostos do próprio gênero a que pertence, precisam ter o mesmo zelo que qualquer outro poema em sua estrutura, a fim de evitar percepções negativas acerca dessa produção, como colocado por Martha (2012, p.47):

A convicção de que a poesia dedicada a crianças e jovens deve ser concebida com base nos pressupostos gerais do gênero fundamenta o tratamento analítico de versos dirigidos a esses receptores, pois quando tratamos de poesia não devemos correr o risco de cair em falsas prerrogativas, responsáveis pelos preconceitos que veem o gênero, e toda a produção infantil e juvenil, como moralista, infantilizado, ufanista e piegas.

Os recursos que consistem no jogo do texto poético, suas colocações sonoras e imagéticas também são atrativos para o leitor que está desenvolvendo novos aspectos de sua cognição. Um dos traços que diferencia a poesia para os mais jovens é a abordagem temática que é feita nela, portanto, o modo como o tema é traba- 
Ihado a fim de alcançar e envolver o seu público. Dessa forma, enquanto construção, o poema é independente do receptor, podendo explorar criações simbólicas diversas por meio da linguagem e apresentar diferentes tipos de versos, estrofes, rimas e ritmos.

Com respeito à maturidade intelectual do receptor, as imagens suscitadas na leitura, e os recursos utilizados para isso, podem auxiliar na entrada do leitor no texto, envolvendo-o no poema. Dessa maneira, considerando o desenvolvimento cognitivo da criança e o do adolescente, é possível utilizar diferentes recursos linguísticos que favoreçam a aproximação com o texto poético dentro do horizonte de cada faixa etária.

Refletindo sobre a construção da subjetividade dos adolescentes por meio da leitura poética, Rêgo (2013) afirma que esta pode tornar-se uma aliada dos jovens que procuram experimentar o mundo, conhecendo-o e, ao mesmo tempo, construindo a sua subjetividade perante a realidade que os afeta. Essa relação do texto literário com a vida dos leitores também é vista em Pinheiro (2018), para o qual os textos devem, sim, serem aproximados das vidas dos leitores, mas é preciso também chamar a atenção para o efeito estético dos recursos no poema em questão.

Ao analisar a produção de poemas que prezam mais pela temática do que pela natureza do próprio texto poético, Silva (2009) afirma que essas obras parecem banalizar o conceito de poesia e carregam consigo uma ideia simplista do gênero, justificando:

\begin{abstract}
A tentativa de criar poemas para públicos específicos parece banalizar o próprio conceito de poesia, pois traz em si a ideia de que podemos classificá-la de acordo com o público para o qual se quer endereçá-la. Tal intenção também veicula uma ideia simplista de poesia, fato que se verifica quando lemos mais detidamente os poemas que integram os livros. Um índice claro desse caráter simplista que marca os poemas se evidencia na repetição dos temas recorrentes nesses textos, constatação feita a partir da catalogação dos poemas nos livros selecionados para estudo. (SILVA, 2009, p. 59).
\end{abstract}

Nessa reflexão, há um questionamento quanto à possibilidade de classificação da poesia, contudo, nem sempre um poema de temática mais madura encontrará abertura com os jovens leitores, mesmo com as melhores das mediações, se eles não tive- 
rem com o quê associar e se sensibilizar. Por isso, a importância de uma literatura juvenil que considere o adolescente enquanto protagonista e sujeito de suas leituras.

Diferenciamos a produção juvenil da infantil não somente por questões de experiência de vida do receptor, mas também por causa das diferenças psíquicas entre eles. Novas habilidades são desenvolvidas na adolescência como consequência das transformações corporais e hormonais dessa fase, tendo em vista que essas também afetam a cognição do adolescente, como apontado por Becker (2003, p. 26):

\footnotetext{
A capacidade de engendrar possibilidades, formular hipóteses e pensar a respeito de símbolos sem base na realidade permite ao adolescente passar a especular, abstrair, analisar, criticar. Essa transformação na inteligência afeta todos os aspectos da sua vida, pois ele utiliza as novas capacidades para pensar a respeito de si mesmo e do mundo que o cerca.
}

Todos esses elementos podem despertar no adolescente, que experimenta a leitura de poemas, diferentes formas de pensar sobre si e sobre o mundo, colocando-o numa posição mais crítica do que quando criança. Essa percepção, quando associada com a poesia, pode ser bastante proveitosa para a realização do jogo do texto poético, assim como para o próprio processo de questionamentos e descobertas da adolescência, uma vez que, como dito por Machado (2012), a poesia pode cumprir a necessidade de se experimentarem afetos, tensões e angústias que muitas vezes os jovens acreditam ser somente deles.

Corroborando com a ideia acima, Rêgo (2013) afirma que a literatura pode se revelar como uma possibilidade de dar sentido a tudo o que o sujeito sente, vive e percebe, como um movimento de introspecção. Passamos, então, a falar de uma literatura juvenil em que o leitor não apenas se identifique com a leitura, mas sinta-se parte dela, quer ele já tenha vivenciado ou não as experiências lidas.

Souza (2011) aborda essa preocupação com a introjeção do destinatário como uma característica da literatura juvenil e, apesar de o fazer falando sobre a narrativa, podemos associar esta preocupação com a poesia juvenil, considerando que o públi-

Interdisciplinar, Sầo Cristóvăo, UFS, v. 33, jan-jun, p. 30-47, 2020 D0I: https://doi.org/10.47250/intrell.v33i1.14175 
co pretendido é o mesmo. Outros aspectos dos textos narrativos para jovens que também se assemelham com o que encontramos na poesia é a representação de situações próprias da adolescência, assim como a presença de um eu lírico adolescente, o que evidencia a possível relação de identificação e introjeção com os poemas para jovens.

Além das vivências particulares da adolescência, qualquer sentimento, experiência ou devaneio pode ser tema para os textos poéticos dos jovens leitores. Ainda sobre a temática, Martha $(2012$, p. 47) afirma que qualquer assunto pode interessar aos jovens leitores e discorre sobre como apresentar as temáticas para as crianças e os jovens:

Quanto à temática, não há nada definido; qualquer assunto pode ser de interesse de tais leitores, desde que Ihes seja apresentado com clareza e respeito ao seu desenvolvimento intelectual e emocional. 0 essencial é que as produções cativem seus leitores com o recurso à fantasia, por seu caráter de magia, pela valorização da sensação que os transporta do mundo real para o possível, construído pelas imagens e símbolos do poema. Desse modo, podem tratar de medos, perdas e ganhos, sentimentos diversos que contaminam o espírito do ser humano.

Diante disso, o que precisa ser pensado especificamente para esse público não é uma temática, mas a forma de abordagem do tema. Se o assunto será tratado de forma tênue, mais figurada, devido a idade de seu leitor; ou se mais direta, compreendendo que o adolescente já tem maturidade para o assunto em questão e para os recursos estruturais utilizados. Passemos, pois, a uma leitura de uma obra poética voltada para o leitor jovem.

\section{Passeio pelo metrô}

Dentro do quadro geral da literatura infanto-juvenil brasileira, Sérgio Capparelli se sobressai pela importante obra no âmbito da poesia e da narrativa infantil, que ele vem produzindo desde o fim da década de 70. Especificamente sobre a sua poesia para os mais novos, o poeta tem "[...] diversos poemas que apresen- 
tam caminhos a trilhar o imaginário, a sensibilidade, o lúdico e a fantasia infantil [...]" (SANTOS, 2019, p. 38). Quanto à produção de poesia para o público juvenil, Capparelli tem cinco livros escritos desde a década de 80.

Sua obra pioneira para os jovens leitores é Restos de arco-íris, publicada em 1985. Posteriormente, veio 33 ciberpoemas e uma fábula virtual, em 1996. Anos depois, em 2004, O duelo de Batman contra MTV e, após 10 anos, O rapaz do metrô: poemas para jovens em oito capítulos ou chacinas, em 2014. Mais recentemente, em 2019, o poeta publicou Poemas para jovens inquietos, revisitando e reunindo poemas das obras anteriores, assim como lançando poemas inéditos.

Em reflexão sobre os dois primeiros livros, Pinheiro (2000, p. 21) ressalta que elas têm "como matéria de seus poemas, experiências de jovens adolescentes: seus conflitos, paixões, desejos, afetos, fobias e inseguranças." e destaca ainda que o diferencial das obras do poeta gaúcho é "o nível poético alcançado" que "confere a seus poemas um destaque no quadro geral da poesia produzida para leitores jovens." (PINHEIRO, 2000, p. 22). O escritor utiliza, modifica e brinca com a linguagem ao criar os poemas, mais do que uma representação, há uma autonomia da língua e dos recursos poéticos em sua produção.

Uma característica em comum entre essas obras de Capparelli é o teor narrativo dos livros, em alguns mais fortes do que em outros, como, por exemplo, em $O$ rapaz do metrô: poemas para jovens em oito capítulos ou chacinas. No entanto, importa frisar que os poemas podem ser lidos na sua individualidade, o que confere a esses textos várias possibilidades de leitura e de vivência pelo leitor. Refletindo sobre poemas narrativos, Sales (2012, p. 140) afirmas que esses textos são "[...] narrativas com personagens em ação numa história contada linearmente (começo, meio e fim) e distinguem-se por se apresentar em versos, conter algum sentido figurado ou metafórico e quase sempre exploram o humor [...]". Diante disso, o livro se apresenta como uma narrativa contada em versos, tendo, inclusive, personagens e uma linearidade em sua trama.

A obra é narrada por um adolescente da periferia de São Paulo que navega entre as estações, os metrôs, os bairros e as diferentes pessoas envolvidas ou afetadas pelas chacinas que es- 
tão acontecendo no bairro em que ele mora. Mesmo com esse teor narrativo, a criação imagética advinda do texto poético não é negligenciada. O livro é composto por 88 poemas ${ }^{4}$ que assumem, mediante um contexto, um caráter de denúncia social. Formalmente, comparecem diferentes tamanhos de estrofes compostas, em sua maioria, de versos livres e com a presença e ausência de rimas e ritmos diferenciados.

Enquanto o eu lírico exprime, por meio de sua angústia e incerteza, a violência em Campo Limpo, temos também um olhar sobre as relações humanas e os sonhos do protagonista e daqueles que passam pela vida dele. Tratando de uma realidade bem específica de uma comunidade que está em constante conflito com policiais e criminosos milicianos e do tráfico de drogas, há a presença de um vocabulário próprio dessas relações, tendo, inclusive, uma nota de rodapé explicando alguns termos que o autor chama de gírias policiais (CAPARELLI, 2014, p. 25). Além disso, vemos também uma certa brincadeira com neologismos a partir de outro idioma5 (CAPPARELLI, 2014, p 30).

A temática e o modo como ela foi trabalhada pelo poeta aproxima essa obra da natureza das narrativas policiais contemporâneas que, segundo Cademartori (2012), optam por tratar do crime e do modo como ele se abriga no silêncio, no medo e, principalmente, na indiferença dos que não querem ver. Se nas narrativas policiais, temos o crime sustentado pelo silêncio e pelo medo, nos poemas narrativos, as ações são, de acordo com Sales (2012, p. 142): “[...] motivadas invariavelmente por personagens diante de um conflito que exige o enfrentamento e ou resolução, o que pode levar o leitor à fruição ou à vivência do que vive a personagem".

Em entrevista para um artigo de Santos e Emerim (2018), o autor enfatizou a preocupação social como central nas escolhas dos temas e na definição do estilo da narrativa científica e literária de sua obra. Diante disso, vemos um protagonista no centro da realidade de uma classe social vulnerável. Emaranhado por um fio narrativa na construção poética e imagética, como no poema abaixo, temos a possibilidade de introjeção do leitor no texto, que pode assumir para si a vivência do eu lírico:

${ }^{4}$ Sendo um desses poemas em inglês.

${ }^{5}$ Esse neologismo acontece no poema "Cáspite, te amo!" e também está presente no conto Meg Foguete (CAPPARELLI, 1997).

Interdisciplinar, Săo Cristóvăo, UFS, v. 33, jan-jun, p. 30-47, 2020 D0I: https://doi.org/10.47250/intrell.v33i1.14175 
Logo agora, que tudo parecia [nos eixos,

Esse toque de recolher

Ninguém sabe quem deu a [ordem,

Se o exército do tráfico

Ou policiais fora de serviço.
O efeito é o mesmo.

Na E. E. Professor Messias [Freire

Aulas suspensas

Até a semana que vem.

Mas quem colocou o cartaz?
Padarias baixam portas de [aço,

Mães recolhem roupa do [varal,

A pracinha fica logo

deserta.

A quem gritar socorro! (CAPPARELLI, 2014, p.

132).

Na primeira estrofe, temos a insatisfação com o toque de recolher; já a partir da segunda estrofe, vamos mergulhando na sensação da incerteza de quem é o inimigo, uma vez que até quem os deveria proteger, não o faz. O medo habita nos moradores de Campo Limpo, pois quem quer que tenha dado a ordem: "O efeito é o mesmo". Há uma interrupção na vida dos que moram naquele bairro, que, ao fim do poema, nem perguntam, mas exclamam em um só verso, sozinhos, "A quem gritar socorro!", no desespero de não ter a quem recorrer.

Além de percebermos aqui uma semelhança com as narrativas policiais já mencionadas neste artigo, vemos também outras características dos conflitos nos poemas narrativos, como: "[...] luta por liberdade da personagem (o herói), busca de uma pessoa querida, disputa entre dois rivais, construção da própria identidade, a batalha pela sobrevivência." (SALES, 2012, p 146). Neste caso, o protagonista tem como conflito a própria realidade violenta em que ele está inserido, assim como a decisão de entregar, ou não, para a polícia, a filmagem que ele, acidentalmente, fez de um assassinato:

\section{Cena do crime}

Repasso a cena do crime. O matador tem uma verruga Que resulta clara, mas preta, No canto esquerdo da boca. É um indício para quem? Penso nisso, comovido

Por tudo que sei que sei:
Corro perigo.

O dias no Campo Limpo Vão de chacina em chacina.

Pouca gente nos velórios, E muitos atrás das cortinas. (CAPPARELLI, 2014, p.57).

A narratividade do poema está em todas as estrofes, seja descrevendo o assassino, pensando sobre sua segurança ou refletindo sobre a rotina de chacinas em Campo Limpo em cada quadra, assim como os recursos poéticos também não são negligenciados no texto. O pleonasmo, no terceiro verso da segunda 
estrofe "Por tudo que sei que sei", enfatiza o pouco que o eu lírico sabe e fortalece a imagem do perigo que ameaça se concretizar.

De acordo com Bosi (2000), a imagem no poema é uma palavra articulada. E é a articulação de palavras da terceira estrofe que mais nos sensibilizam neste poema, com uma imagem que nos traz o tempo não mais passando em dias ou em horas, mas "de chacinas em chacinas" e com os questionamentos despertados na leitura de "Pouca gente nos velórios/E muitos atrás das cortinas". Ainda a partir dessa estrofe, podemos retornar para a reflexão comparativa com as narrativas do gênero policial quando Cademartori (2012, p. 77-78) fala sobre o enredo nas histórias policialescas atuais:

\footnotetext{
Hoje, a tônica recai no desconforto generalizado frente à violência, à exclusão e à impunidade. $\mathrm{O}$ assassino não pode mais ser encontrado com base na antiga chave, constituída pela pergunta: quem, entre as personagens, tem, de fato, motivo para matar. Isso não vale mais, quando o que gera o crime é o ressentimento social e o ódio indiscriminado. $O$ assassino, nesse quadro, pode ser qualquer um. E o matador não será fatalmente castigado pelo sistema.
}

Não se sabe quem são os que estão atrás das cortinas, eles estão escondidos e podem ser qualquer um. Em muitos poemas, surge o questionamento quanto a identidade dos assassinos, deixando claro a possibilidade de, inclusive, serem aqueles que deveriam proteger os moradores. Durante a leitura, acompanhamos uma vida na iminência de uma nova chacina. Ler os poemas é entrar no metrô e passear por São Paulo, assim como é também passear pela dor do racismo e discriminação social que afeta a população de Campo Limpo e pelas lembranças dos assassinatos recorrentes; é acompanhar o processo reflexivo e de amadurecimento do adolescente que se vê sozinho diante de seus dilemas:

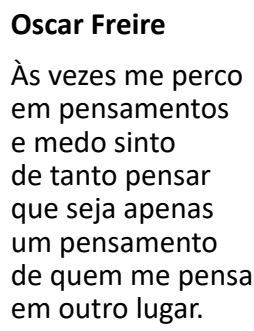

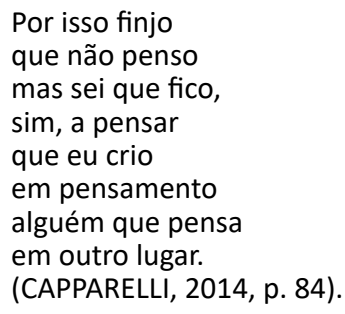


Enfrentando, sozinho, um conflito, temos um poema que, de certa forma, brinca com a língua; há uma espécie de encadeamento entre a primeira e segunda estrofe, como uma brincadeira entre palavras e as imagens que essas palavras vão criando em todos os versos. Segundo Bosi (2000), contexto expressivo e tom sempre andaram juntos. Em todo o poema, há um tom de temor despertado pelo contexto; o adolescente teme as consequências de ser reconhecido por ter filmado o assassinato, "que seja apenas/um pensamento/de quem me pensa/em outro lugar". No entanto, a leitura é um ato criativo e a percepção do tom do texto varia de acordo com a intencionalidade proposta, uma vez que, de certa forma, a entoação pode situar o texto. Enxergamos aqui, então, uma narrativa que, fora do enredo do livro, pode assumir um tom diferente, mais suave, de brincadeira, suscitado pela sonoridade nas estrofes.

Recursos como a aliteração com o som oclusivo do [p] e da sibilante [s], "Às vezes me perco/em pensamentos/e medo sinto/ de tanto pensar/que seja apenas" e a repetição de palavras como "pensamento", "pensar", "penso" e "pensa" são constantes nos versos do poema e trazem toda uma musicalidade para a leitura. Esses recursos são próprios da poesia como um todo, mas, em especial, na literatura infantil, a musicalidade aproxima a criança ao poema. Aqui vemos um protagonista que está no meio termo, saindo da infância e partindo para outra fase, mais independente, da vida.

A trama se mostra no conflito interno do eu lírico e os recursos poéticos utilizados trazem a fragilidade do adolescente diante desse conflito, com a predominância de versos livres nos poemas que, muitas vezes, também não seguem uma estrutura fixa nas estrofes. Não é que haja um choque quanto ao processo de amadurecimento do adolescente, mas uma resistência à situação que ele está vivenciando, uma vez que nos versos "que eu crio/ em pensamento/alguém que me pensa/em outro lugar", podemos ver no eu lírico um desejo de estar em outra realidade. Diferente do fim da primeira estrofe, onde ele teme estar nos pensamentos de alguém em outro lugar.

Algo recorrente nas narrativas policiais contemporâneas, segundo Cademartori (2012), é a banalização da violência de tal modo que passamos a conviver com as suas representações como 
forma de divertimento. Na leitura do poema acima, temos um eu lírico em meio a um conflito que é consequência da violência, mas não há prazer em ver o que nos é apresentado, o que existe é a fruição que leva o leitor a vivenciar a dúvida, o medo e a insegurança do adolescente. No entanto, não é apenas o ponto de vista do adolescente que está presente no livro de Capparelli. Há poemas nos quais o eu lírico mantém-se presente, mas empresta seu protagonismo para outras vozes, nos dando diferentes vivências da mesma situação, como abaixo:

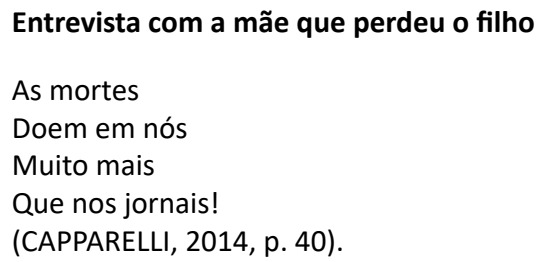

Nesse poema, em uma quadra, temos outro ponto de vista das chacinas, o discurso de alguém que, de uma maneira diferente, foi afetado pela mesma violência. A facilidade de leitura desse poema, com a rima do terceiro e quarto verso, com a tônica que se repete, toma um tom mais pesado junto ao título. Esse título, nesse contexto, dá um indicativo da presença do protagonista e anuncia a perspectiva de outras vítima das chacinas. $E$ apesar de a voz do poema não ser mais de um adolescente, é possível o jovem leitor aproximar-se do texto da mesma forma, seja pela perspectiva daquele que assiste a entrevista, o protagonista de 16 anos, seja pela empatia despertada pela dor no discurso da mãe. Todos resultados de uma criação artística que leva o seu leitor à fruição e reflexão, por meio de um encontro estilístico com as consequências do desprezo social de um sistema excludente e aterrorizador.

Podemos nos deparar, ainda mais fortemente, com a desigualdade social e com a identificação de diferentes vozes no poema "Aleluia". Neste, já finalizando a narrativa, anuncia-se a prisão dos assassinos ao mesmo tempo em que, a cada estrofe, se constroem diferentes imagens de quem eles podem ser e a quem eles podem estar associados: 
Aleluia

O ônibus seguia lotado Quando alguém anunciou: Prenderam os assassinos.

Que pena! crocitaram Os urubus em revoada: Eles eram nossos amigos.

E toda a Vila das Belezas A seguir cantarolou: Prenderam os assassinos.
Lobos gordos, em alcateia, Ulularam na Sibéria:

Que Saudade de nossos [amigos!

O sol que no alto luzia

Franzino se iluminou:

Prenderam os assassinos.

As hienas, a uma só voz: 'Oceis são piores que nós, Adeus, podres amigos!
Consolação e Paulista De mãos dadas em ciranda: Prenderam os assassinos.

A banda podre de Tudo Diz à podre banda do Nada: Quando nos veremos [amigos?

(CAPPARELLI, 2014, p.136).

Voltemos aqui a falar do tom da leitura. Segundo Bosi (2000, p. 120), "o tom opera uma transposição dos altos e baixos emotivos para a pauta da significação". Neste poema o tom pode variar a cada estrofe. Formada por oito estrofes de três versos, cada terceto apresenta um grupo, ou parte de grupos, reagindo à prisão dos assassinos, são diferentes vozes que se colocam no mesmo poema. No começo, com aqueles que estão no transporte lotado, realidade mais presente na rotina das classes mais vulneráveis, escutando sobre a prisão.

Na segunda estrofe, as imagens construídas são mais figuradas, resultado de um imaginado que, enquanto imagem "tem um passado que a constituiu; e um presente que mantém viva e que permite a sua recorrência" (BOSI, 2000, p. 22). Dessa forma, aquilo que conhecemos age sobre as nossas percepções do que estamos lendo e sentindo no momento. Sendo assim, os urubus, animais vistos como sujos, que voam e se alimentam de carne morta, consideram os assassinos como amigos, assim como os lobos, animais mais ferozes, predadores, o fazem, sentem saudade desses amigos.

Em outra estrofe, diferente desses animais, as hienas, que também têm uma fama de caçadoras e carniceiras, se distanciam dos assassinos, afirmando que eles são piores do que elas e adjetivando-os de podres, sem, contudo, deixar de se referirem a eles como amigos. E entre os urubus e os lobos, a Vila das Belezas, bairro de nome tão atrativo que, da mesma maneira que o seu vizinho, Campo Limpo, sofre com bastante violência, comemora a prisão, assim como, em outra estrofe, Consolação e Paulista. Esses dois últimos bairros são de classe alta, logo, vemos diferentes grupos sociais com a mesma reação para a prisão. A cada estrofe, o tom traz uma significação suscitada por um contexto.

Interdisciplinar, Sằo Cristóvầo, UFS, v. 33, jan-jun, p. 30-47, 2020 D0I: https://doi.org/10.47250/intrell.v33il.14175 
Na última estrofe, podemos reiterar, ainda, o que diz Cademartori (2012) sobre a indefinição de quem é o assassino na narrativa contemporânea: "A banda podre de Tudo/ Diz à podre banda do Nada:/ Quando nos veremos amigos". Como visto em "Toque de recolher", os assassinos podem ser qualquer um, inclusive aqueles que deveriam proteger a população. Sem um suspense construído para vender a violência como entretenimento, há textos poéticos sensíveis e densos que despertam afeição e reflexão no jovem leitor. Pensando nesse despertar, descrevemos adiante uma vivência com um poema dessa obra.

\section{Do Metrô à sala de aula}

Dentre as várias experiências que realizamos com poemas juvenis de Sérgio Capparelli em sala de aula, apresentamos aqui a recepção do poema "Oscar Freire ${ }^{6 "}$ com uma turma do primeiro ano do ensino médio. Levamos o poema fragmentado em versos para a sala de aula, sem conhecimento do original, para que os alunos ordenassem os versos de forma que (re)criassem um poema. A turma foi separada em dois grupos, que, livremente, foram experimentando novas possibilidades. Numa delas, em que não utilizam todos os versos, temos esta criação:

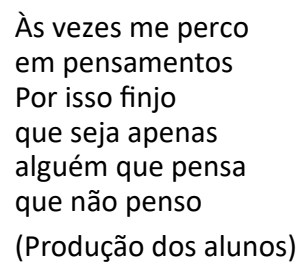

Aqui os colaboradores dão mais destaque à sonoridade, que pode ser observada na aliteração do /p/. A manipulação dos versos partiu daquilo que despertavam nos alunos semântica e sonoramente. Em determinado momento, eles chegaram a afirmar que queriam produzir um poema em que o medo fosse algo criado pelo eu lírico. Ao utilizar todos os versos, já em seguida, eles alteraram a sequência, buscando outra criação que evidenciasse a significação por eles pretendida. Na tentativa de construir

${ }^{6}$ Trata-se de um pequeno recorte de nossa dissertação de Mestrado em construção no PPGLEUFCG, e que reflete sobre um experimento com poemas de Sérgio Capparelli. 
o poema, eles estavam envoltos no próprio processo de leitura, o qual, segundo Iser (2002), ocorre a partir de uma dupla operação de imaginar e interpretar um mundo a ser identificado.

Abaixo, trazemos a segunda criação que resultou dessa atividade:

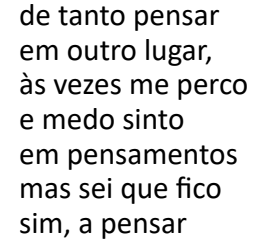

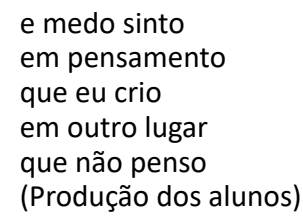

Os alunos apresentaram suas criações e, posteriormente, escutaram o poema original. Durante a leitura de "Oscar Freire", ficaram atentos e perceberam uma similaridade entre a criação acima e o poema de Sérgio Capparelli, por isso pediram para comparar os textos mais minuciosamente. No decorrer do processo de leitura e comparação entre os poemas, vibravam com o que se assemelhava, sem que se sentissem menores pelo que era diverso. No fim, a noção de jogo, como apresentada por Iser (2002) esteve presente a todo momento, não importando as similaridades e as diferenças entre o poema original e o que foi criado pelos alunos, mas, sim, a vivência compartilhada, resultando, inclusive, no desejo de explorar mais o texto, dessa vez, pelo corpo.

$\mathrm{Na}$ apresentação/encenação do segundo exemplo, os dois leitores colocaram um capuz e um foi para o centro da sala, leu a primeira estrofe, hesitando entre os versos e olhando ao redor como se estivesse assustado e à procura de alguém. Em seguida, ele se agachou e cobrindo o rosto ficou nessa posição até o outro leitor se aproximar e performar a segunda estrofe andando ao seu redor. Nesse momento, a leitura foi mais energética: o leitor batia seus braços no coração e, ao finalizar, fez do último verso uma pergunta, repetindo-o e questionando a realidade daquele receio. Por fim, ele tocou no outro leitor, que se levantou e os dois, como partes do mesmo medo de uma realidade, se retiraram. 0 que destacamos aqui são os diferentes caminhos de leitura para o mesmo poema, as significações e entregas distintas, atualizadas a partir daqueles que as leram. 
Considerando as diferentes formas de exploração do poema, o encontro com o texto se torna vivo e pode ser, um jogo para o seu leitor. Por certo, esse jogo de leitura poderá contribuir com o autoconhecimento, com uma percepção mais atenta da realidade, de seu lugar no mundo, dos diferentes lugares que ocupamos, seja no plano social, seja nas particularidades de cada sujeito. E a discussão, ao final de todo o processo, revelou que de fato os alunos, através do jogo com os versos, tiveram uma experiência estética, naquele sentido que Jauss (1979) denomina de poiesis, isto é, o poema foi recriado pelos leitores a partir de suas vivências, reflexões, tentativas de ordenação.

\section{Consideraçôes finais}

Apesar de ainda escassa, temos uma produção de poemas juvenis que se diferencia da infantil devido às vivências distintas entre essas faixas etárias e ao desenvolvimento da maturidade intelectual nesses momentos da vida. Em uma fase mais consciente de si e do mundo, o jovem pode ler com fruição diversos temas, mesmo os mais intensos e profundos, se pensados ou mediados considerando o receptor e suas experiências de vida.

Em nossa reflexão, encontramos na produção de poemas narrativos organizados em capítulos, ou chacinas, um diferencial nessa obra. Sem que impeça a leitura isolada dos textos, essa narratividade é uma característica da lírica de Sérgio Capparelli que aparece também em outras obras do poeta para o público juvenil. Em Duelo de Batman contra a MTV (2004), por exemplo, há diferentes perspectivas dos encontros e desencontros da relação entre um pai e seu filho.

Da mesma forma, notamos esse traço narrativo em Restos de arco-íris (2011), no qual o poeta explora as descobertas do começo da adolescência, com um olhar sobre as relações afetivas, tendo como pano de fundo o período da ditadura militar no Brasil. Nesse ponto, as obras também se assemelham por abordarem questões sociais. Na primeira, mais sutilmente, o contexto é outro, com eu líricos de classes sociais mais privilegiadas que de $O$ rapaz do metrô. Neste, a temática social não é trabalhada como um pano de fundo, ou uma reflexão isolada, mas como cenário vivo da realidade do eu lírico.

Interdisciplinar, Sằo Cristóvầo, UFS, v. 33, jan-jun, p. 30-47, 2020 D0I: https://doi.org/10.47250/intrell.v33i1.14175 
Ademais, a exploração de diferentes linguagens também é algo recorrente e bem realizado por Capparelli. Na leitura deste trabalho, vimos, principalmente, a utilização das gírias policiais e de discursos próprios da periferia. Já em 33 Ciberpoemas e uma fábula virtual (2009), o escritor vai mais a fundo na temática do amor, utilizando a linguagem dos recursos e expressões do mundo virtual para criar os poemas.

Os caminhos da lírica juvenil de Sérgio Capparelli, visando a aproximação de adolescentes com a poesia são muitos, desde o tema até a estrutura, possibilitando, assim, uma experiência poética e sensível aos jovens. O poeta lança mão de temáticas mais densas, com uma abordagem crítica, como no caso de $O$ rapaz do metrô, sem usar a violência a fim de entreter ou corrigir comportamentos. $\mathrm{O}$ autor não alcança apenas os jovens leitores, mas, ao respeitá-los e incluí-los na temática, na linguagem e até mesmo na estrutura dos textos, comunica-se também com o leitor mais experiente.

\section{Referências}

BECKER, D. 0 que é adolescência. São Paulo: editora brasiliense, 2003.

BOSI, A. O ser e o tempo da poesia. São Paulo: Companhia das letras, 2000.

CADEMARTORI, L. O professor e a literatura: para pequenos, médios e grandes. Belo Horizonte: Autêntica, 2012.

CAPPARELLI, S. O rapaz do metrô: poemas para jovens em oito chacinas ou capítulos. Rio de Janeiro: Galera Record, 2014.

ISER, W. O jogo do texto. In: LIMA, L. C. (Org). A literatura e o leitor: textos de estética da recepção. Tradução Luiz Costa Lima. Rio de Janeiro: Paz e Terra, 2002. p. 105-118.

JAUSS, H. R. et al. A literatura e o leitor: textos da estética da recepção. Tradução Luiz Costa Lima. Rio de Janeiro: Paz e Terra, 2002.

MACHADO, M. Z. V. Depois da poesia infantil, a juvenil? In: AGUIAR, V. T. CECCANTINI, J. L. (Orgs). Poesia infantil e juvenil brasileira: uma ciranda sem fim. São Paulo: Cultura acadêmica, 2012. p. 263-278. 
José Hélder Pinheiro Alves; Livia Marbelle Oliveira Barboza

MARTHA, A. A. P. Pequena prosa sobre versos. In: AGUIAR, V. T. CECCANTINI, J. L. (Orgs). Poesia infantil e juvenil brasileira: uma ciranda sem fim. São Paulo: Cultura acadêmica, 2012. p. 45-73.

PINHEIRO, H. Poemas para crianças e jovens. In: PINHEIRO, Hélder (org) Poemas para crianças: reflexões, experiências, sugestões. São Paulo: Livraria Duas Cidades, 2000. p. 11-32.

PINHEIRO, H. Poesia na sala de aula. São Paulo: Parábola, 2018.

SALES, J. B. O poema narrativo para a infância. In: AGUIAR, V. T. CECCANTINI, J. L. (Orgs). Poesia infantil e juvenil brasileira: uma ciranda sem fim. São Paulo: Cultura acadêmica, 2012. p. 133-151.

SANTOS, I. EMERIM, C. Aspectos teóricos sobre a vida e obra de Sérgio Capparelli. Pauta geral: estudos em jornalismo, Ponta Grossa, v. 5, n. 2, p. 106 - 131, dez. 2018. Disponível em: https://www.revistas2.uepg.br/index.php/pauta/article/view/12304/209209210532. Acesso em: 19 jul. 2020.

SANTOS, J. S. M. A recepção de poemas de Sérgio Capparelli em sala de aula: uma vivência com alunos da do 4ㅇano do ensino fundamental. Dissertação (mestrado em Linguagem e Ensino) - UFCG, Campina Grande, 2019.

SILVA, V. L. Poesia para adolescentes: estudo crítico de obras e vivência em sala de aula. Tese (doutorado em Letras) - UFPB, João Pessoa, 2009.

SOUZA, M. Z. Literatura juvenil em questão: aventura e desventura de heróis menores. São Paulo: Cortez, 2001.

RÊGO, Z. L. G. P. A leitura poética e a construção da subjetividade dos adolescentes. In: AGUIAR, V. T. CECCANTINI, J. L. (Orgs). Poesia infantil e juvenil brasileira: uma ciranda sem fim. São Paulo: Cultura acadêmica, 2012. p. 279-306.

Interdisciplinar, Săo Cristóvăo, UFS, v. 33, jan-jun, p. 30-47, 2020 D0I: https://doi.org/10.47250/intrell.v33il.14175 